\title{
REDD+ and Community Forestry in Nepal: Strengthening or Paralysing Decentralised Governance?
}

\author{
Dil Khatri, ${ }^{1,2}$ Gyanu Maskey ${ }^{1}$ and Bikash Adbikari ${ }^{3}$ \\ ${ }^{1}$ Southasia Institute of Advanced Studies, Kathmandu, Nepal, \\ ${ }^{2}$ ForestAction Nepal, Kathmandu, Nepal and ${ }^{3}$ Institute of Forestry, Pokhara, Nepal \\ Corresponding author: khatridb@gmail.com
}

\begin{abstract}
At a time when community forestry has become a prominent mode of forest governance in many developing countries, REDD+ (Reducing Emissions from Deforestation and Forest degradation) has emerged as a new conservation policy to contribute to climate change mitigation by incentivising such countries to conserve forest. While the proponents of REDD + claim that it can help to strengthen decentralised forest governance through an increased flow of resources of fund and knowledge, the critics evince that there are negative consequences of REDD+ implementation to the decentralisation process, local control, and access to forests. Drawing on the ongoing engagement of the authors in the national REDD + policy process and an ethnographic study of the REDD + initiatives in Nepal, this paper demonstrates that REDD+ might paralyze Nepal's long-standing community forestry policy rather than strengthening it. Findings show the instrumental use of participation in REDD + policy development and limited representation of local voices in the policy processes. The piloting project implemented on community forestry suggest that REDD + , if implemented at full scale, can put new demand(s) to the long-standing community forestry policy and practices resulting in threatening of local uses of forests by smallholders. The implementation of REDD + is likely to reshape community forest management practices driven from the priority of generating revenue which in turn undermines the need to manage forests to meet diverse needs of the smallholders. This analysis indicates the need for paying greater attention to represent local voices in developing national policies and programs, and align REDD + objectives to the core principles of community forest management, local access, and control of forests.
\end{abstract}

Key words: Access, community forestry, climate change, forest governance, Nepal

\section{INTRODUCTION}

Community Forest User Groups (CFUGs) have received additional income from REDD+ piloting. I think this is a reward for their contribution to forest management. Poor and marginalised people from the groups have benefited directly from REDD+ payments. In addition, we also had the opportunity to develop capacity on $R E D D+$ and we are abead of many other districts in terms of REDD+ implementation.
This was the response from the Chairperson of the Community Forestry Federation in Dolakha to our query about the possible consequences of REDD $+{ }^{1}$ implementation to local rights. During an interview on November 2014, she was talking about the Norwegian Agency for Development Cooperation (NORAD) funded REDD + pilot project implemented during 2009-2013. The project aimed to demonstrate REDD+ implementation in Nepal's Community Forests (CF) and

\footnotetext{
${ }^{1}$ Reducing Emission from Deforestation and Forest Degradation and the role of conservation, sustainable management of forests and enhancement of forest carbon stocks in developing countries.
} 
provide lessons to the national policy development (Shrestha et al. 2014: 2439). The piloting has specific significance as REDD + in Nepal had intended to build on the established CF institutions and gain from their past achievements with regard to institutional mechanisms and recovery of the forests (Newton et al. 2015; Paudel et al. 2015).

This observation brings us to the ongoing debate about possible implication(s) of REDD + on CF which has become a prominent mode of forest governance in many developing countries (Agrawal et al. 2008). It appears that REDD + has been received positively by the leaders of local forest user groups and representatives of their federations (see quote above). Such positive perception may be because of the way REDD + has been portrayed by the proponents of piloting at the local level. As the first author observed in the meetings organized by the pilot project in Dolakha, the CFUGs and the local Federation of Community Forestry Users Nepal (FECOFUN) officials explained about REDD + and portrayed it as source of additional revenue to CF. It has also been said that REDD+ can bring new opportunities for knowledge and funding at the local level which can help strengthen $\mathrm{CF}$ implementation and support livelihood (Skutsch et al. 2012; Shrestha et al. 2014). Moreover, it is also mentioned in the project's publication that REDD+ can provide the local communities (i.e. CFUGs) with the "opportunity to partake in global REDD + finance" (Skutch et al. 2012: 1).

However, there are growing concerns that REDD + implementation can have negative consequences to $\mathrm{CF}$ by affecting the decentralisation process and local benefits from forest management. Some scholars warn about the possible risk of re-centralisation in forest governance (Sandbrook et al. 2010; Phelps et al. 2010). The pro-decentralisation authors see REDD + as a threat that can reverse current trends in the forest governance structures of REDD + countries. For example, Phelps et al. (2010) see REDD + as a threat to centralisation of forest governance (also see Vijge et al. 2016). It is argued that the centralised forest governance driven by REDD + implementation can lead towards curtailing of existing practices of using forests by forest-dependent communities (Sandbrook et al. 2010). Further, literature also indicates that increased financial flow through REDD + implementation is likely to increase the value of forests which provide incentives to the government bureaucracy to recentralise the control (Sandbrook et al. 2010; Phelps et al. 2010). Some studies even suggested the risk of the shift in control of forest by local communities towards external actors and interests i.e. international organisations, challenging local control and benefits of CF management (Leach and Scoones 2015).

This paper intends to contribute to this critical scholarship by examining REDD + policy development and a piloting initiative undertaken in Nepal with specific focus on what REDD+ implementation would mean for CF governance. The analysis of the policy process will focus on participation and representation of local voices whereas the examination of piloting will focus on how the interventions are carried out at the local level and with what effects to the existing local benefits from CF. We demonstrate how the particular 
framing of REDD + and implementation of interventions under the pilot can give rise to the changes in discourses and practices of $\mathrm{CF}$ management. Analysis also pays attention to who defines the basis, priorities, and process of forest governance at the local level, reshaping management practices, and distributional outcomes.

Nepal's CF is an exemplary case to understand the effects of REDD+ implementation on forest decentralisation. In Nepal, the REDD+ development intends to build on the well-established CF program ${ }^{2}$ which has been regarded as a key factor for the recovery of once degraded mountains (Gautam et al. 2003; Niraula et al. 2013) leading to the improved provisioning of diverse Ecosystem Services (ES) to fulfill the needs of the local people (Adhikari et al. 2007; Thoms 2008; Marquardt et al. 2016). Further, the devolution policy in Nepal that provides the local community with rights to management and use of forest has been defended by a well-established civic movement led by the FECOFUN, a grassroot organisation of over 18,000 CFUGs established in $1995^{3}$. Nepal's REDD+ policy development has been considered to be participatory and inclusive by its proponents since the key Civil Society Organisations (CSOs) like FECOFUN and Nepalese Federation of Indigenous Nationalities (NEFIN) are involved in the policy development process. Yet, there has been ongoing demand from some CSOs representing women and $\mathrm{Dalit}^{4}$ for greater representation of their voices. As the quote (in Introduction) shows, the involvement of key CSOs in REDD+ development converted them as promoters of the REDD + instead of defenders of local rights (Ojha et al. 2013). We will inspect these dynamics by examining the role of key CSOs in the national policy making and project implementation. The analysis will focus on the question of how implementation of piloting incorporated these actors in the role of activists and consequences that might have had on local rights.

After a brief outline of the methods (in section two), we present the analysis of national policy development focusing on the representation of local voices (section three). Then we present the examination of the REDD + piloting focusing on the interventions and their effects (section four). We move to examine the role of key CSOs in the REDD + policy development and local interventions focusing on how local voices are incorporated into the mainstream process of REDD+ implementation. The findings have been discussed (in section six) focusing on what REDD + process means for the CF policy and practices. The paper concludes (in section seven) with some policy implications for REDD + development and implementation in the future.

\footnotetext{
${ }^{2}$ With about four decades of history, community forestry became a prominent forest governance model in Nepal. About one-fourth of the country's forest is managed under this regime and it is lauded for achievement to revert the deforestation in the hills.

${ }^{3}$ Established in the early 1990s, FECOFUN represents over 18000 CFUGs in the country and acts as a pressure group against the state to defend the rights of the community over forest resources.

${ }^{4}$ According to the National Dalit Commission (NDC), Dalits are defined as "those communities who, by virtue of atrocities of caste-based discrimination and untouchability, are most backward in social, economic, educational, political and religious fields, and are deprived of human dignity and social justice”.
} 


\section{METHODS}

The findings reported in this paper are drawn on the ongoing engagement of authors on national REDD+ policy processes and ethnographic field study conducted during 2012 and 2016 in the REDD + piloting sites of Dolakha and Chitwan. The authors have been engaged in the REDD + development processes in Nepal in various ways. The first author was involved in the REDD Working Group $^{5}$ (RWG) during the period of 2011-2012 representing ForestAction Nepal, a policy think tank in the forestry sector of Nepal. Both the first and second authors were involved in the process of development of the key national REDD + policy documents i.e. Readiness Preparedness Proposal (RPP) and National REDD + Strategy. They have also been actively involved in other events related to participatory Monitoring, Measuring and Reporting (MMR) Guideline 2015, Emission Reduction Program Document (ERPD) and Forest Investment Plan (FIP) 2015. Insights were also drawn from a number of stakeholder forums including the meetings of REDD + CSO Alliance where major CSOs are involved.
Examination of the REDD+ piloting involved review of the documents related to the piloting project and field study conducted in two of the three pilot sites. The review covered documents such as procedural manuals (i.e. manual for 'Forest Carbon Trust Fund'), progress reports, and publications authored by the project staff. We also interviewed people involved in the design and implementation of the pilot project. Field study was conducted in Dolakha (during 2012 and 2015) and Chitwan (during 2014-2016), two out of three pilot sites. Dolakha was selected considering its relatively stronger community forestry program because of its long history of the Swiss support. The findings from Dolakha represent the landscape and forest management of the mountain region of Nepal in which Gorkha (another project district) also falls. On the other hand, Chitwan represents the Chure and Terai regions ${ }^{6}$ that is contrasting in terms of landscape forest management regime and to explore the activities implemented in the REDD+ piloting.

\footnotetext{
${ }^{5}$ A group of 12 individuals, chaired by the Secretary of the Ministry of Forest and Soil Conservation (MFSC) for providing technical \& institutional support to the REDD Implementation Centre (RIC), monitor program activities \& facilitate the development of the REDD + national strategy.

${ }^{6}$ Chure is a foothill that lies between Terai and Mahabharat range extending from east to west of Nepal. It covers about $12.8 \%$ of the total land area of the country ranging and extends from 93 meters to 1,955 meters altitude.
} 


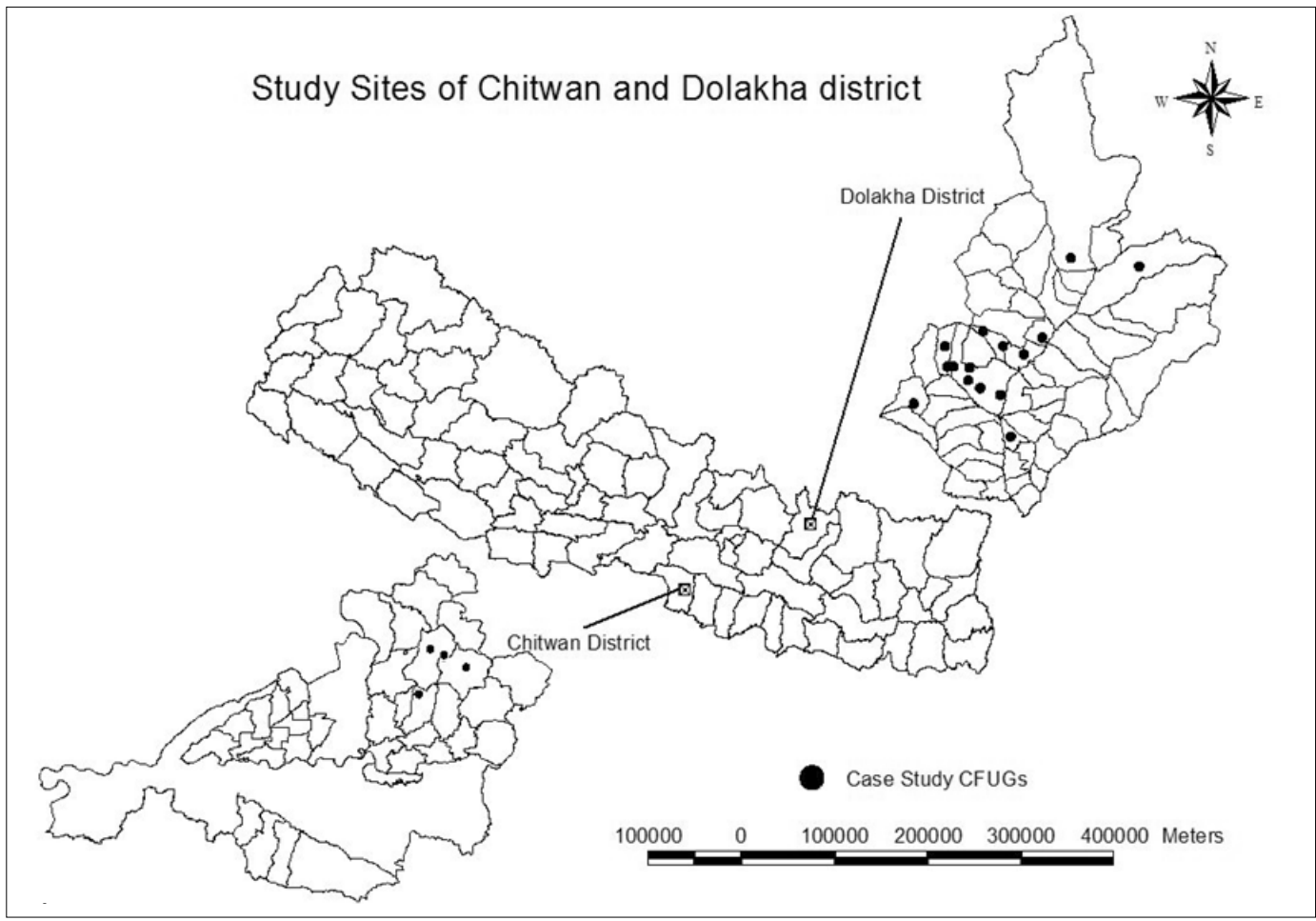

Figure 1: Map Showing Three Project Sites and Research Locations

The field study started with interviewing FECOFUN representatives that helped to build better understanding about project implementation and also towards selecting CFUGs for the study. The CFUGs' selection was based on their variations with regard to forest size, composition and road access. District Forest Officer (DFO) was interviewed focusing on project implementation and forest management practices in CFUGs.

Table 1: List of Interviews and Informants

\begin{tabular}{|c|c|c|c|}
\hline Site/District & CFUG interviewed & $\begin{array}{l}\text { Households } \\
\text { interviewed }\end{array}$ & Key informants interviewed \\
\hline \multirow{4}{*}{$\begin{array}{l}\text { Charnawati } \\
\text { catchment } \\
\text { Dolakha } \\
\text { district }\end{array}$} & \multirow[t]{4}{*}{6} & \multirow{4}{*}{$\begin{array}{l}31 \text { farming } \\
\text { and forest user } \\
\text { households }\end{array}$} & $\begin{array}{l}2 \text { interviews with international } \\
\text { NGO staff }\end{array}$ \\
\hline & & & $\begin{array}{l}2 \text { interviews with national NGO } \\
\text { staff }\end{array}$ \\
\hline & & & $\begin{array}{c}5 \text { interviews with the regional } \\
\text { NGO involved in the pilot }\end{array}$ \\
\hline & & & $\begin{array}{l}3 \text { interviews with government } \\
\text { officials }\end{array}$ \\
\hline
\end{tabular}




\begin{tabular}{|c|c|c|c|}
\hline $\begin{array}{l}\text { Kayarkhola } \\
\text { catchment }\end{array}$ & $\begin{array}{l}4 \text { semi-structured } \\
\text { interview with }\end{array}$ & \multirow{4}{*}{$\begin{array}{l}43 \text { farming } \\
\text { and forest user } \\
\text { households }\end{array}$} & $\begin{array}{l}2 \text { interviews with the regional } \\
\mathrm{NGO} \text { involved in the pilot }\end{array}$ \\
\hline $\begin{array}{l}\text { Chitwan } \\
\text { District }\end{array}$ & $\begin{array}{l}\text { CFUG leadership } \\
\text { (chairperson and }\end{array}$ & & $\begin{array}{l}2 \text { interviews with government } \\
\text { officials at regional level }\end{array}$ \\
\hline & $\begin{array}{l}\text { secretary and } 3 \\
\text { group interviews } \\
\text { with CFUG }\end{array}$ & & $\begin{array}{l}2 \text { interviews with Local Resource } \\
\text { Persons }\end{array}$ \\
\hline & $\begin{array}{l}\text { executive committee } \\
\text { members) }\end{array}$ & & $\begin{array}{l}1 \text { interview with watershed } \\
\text { REDD + coordinator }\end{array}$ \\
\hline Total & 10 & 74 & 19 \\
\hline
\end{tabular}

We also conducted interviews with families from selected households. From each REDD + pilot project CFUG, three households were selected for interview, one each from high, medium and lowincome households (drawing on the ranking done by the CFUGs). In total, we interviewed 74 families. The interviews with the CFUGs in both the project sites focused on involvement of the group and individuals in REDD + related activities, use of REDD + money within the group and practices of forest management before and after REDD + implementation. At the district level, we interviewed key district officials from DFO, NEFIN, FECOFUN and watershed level REDD + coordinator.

\section{REDD+ DEVELOPMENT IN NEPAL TO BUILD ON COMMUNITY FORESTRY: QUESTION OF PARTICIPATION AND REPRESENTATION}

The REDD + program implementation in Nepal will build on the already existing community forestry institutions. The community forestry program in Nepal evolved to overcome the failure of the state-centric governance initiated in late 1950s which was reinforced by the forest legalization in 1965. The peoples' participation in forest management initiated in the late 1970s was formalised as the community forestry program of the current form through Forest Act 1993. The Act formalised the user group-based approach which gained momentum during the 1990s and has now become one of the most successful policy reforms in Nepal.

The Nepal community forestry program includes about 19,361 CFUGs managing $18,13,478$ hectares of national forest and involving about 1.45 million households or 35 per cent of Nepal's population (DoF 2018). The community forestry program offers a variety of positive outcomes, specifically with regard to its contribution to forest recovery by restoring the once degraded hill's forests, improving their conditions in terms of biomass (Gautam et al. 2003; Yadav et al. 2003) and in restoring diverse ecosystem services i.e. stabilizing the mountain slope and contributing to subsistence farming (for example see Marquardt et al. 2016). Further, community forestry is recognised to have been successful in devolution of power to the local people to enable them in making decision over management and use of their forest (Agarwal et al. 2012). Although the government retains ownership of forests, CFUGs are provided with the rights to manage forest and use the resources following a management plan jointly 
agreed upon by the user group and District Forest Office, the local unit of the forestry department. Yet, there are mixed reports about the equity aspect of $\mathrm{CF}$ including its contribution on livelihoods of poor and people from the marginalised communities $^{7}$ (Paudel 1999; Thoms 2008).

This section presents our examination of the national REDD + policy development focusing on stakeholder participation and representation of local voices. Particular attention is given to CSO representation in the national REDD+ development process. We deal with the question of how the representation of FECOFUN and NEFIN in the national REDD + policy development such as RWG addressed concerns regarding the representation of the voices of indigenous people and local communities. We also deal with the question on the extent to which two organisations were able to fully represent the voice of their respective constituencies and why.

The policy development process was led by the Ministry of Forest and Soil Conservation of Nepal and supported by the Forest Carbon Partnership Facility (FCPF) of the World Bank and other donor agencies. Nepal's REDD+ policy process has been considered by its advocates as one of the most participatory and inclusive. For example, the Readiness Preparation Proposal (R-PP) of Nepal was praised by the FCPF as one of the highest ranked ones in terms of participation and inclusion of civic perspectives. The logic behind this was that key CSOs in Nepal including FECOFUN and NEFIN were involved in the R-PP preparation.
However, there have been widespread concerns regarding the representation of local voices in the REDD + policy development (Bushley and Khatri 2011; Ojha et al. 2013; Bushley 2014). There has been limited participation of CSOs in the forums related to REDD + policy making. For example, NEFIN is the only group with representation in the highlevel inter-ministerial Apex Body, and only NEFIN and FECOFUN sit in the RWG and REDD + CSOs-IPOs Alliance. The CSOs representing other marginalised social groups such as women and Dalit feel that they are excluded in the process and have been demanding for inclusion of their voices in the national policy process (Satyal et al. 2018). The issues and voice of diverse marginalised groups including Dalit and women supposed to be represented by these two CSOs have not been put forward as these organisations speak of their constituencies and have their own agenda to focus on. A Dalit representative complained"; "NEFIN representatives do not put forward the issues of Dalits, so a separate representation of Dalit is needed in higher decision-making forums".

While FECOFUN and NEFIN exhibit high stake in REDD+, paradoxically, these organisations have also been involved in different REDD + related interventions and piloting activities as local implementing partners of the international agencies. For example, the FECOFUN was one among the three partners of the REDD + piloting. The involvement of these key civic actors to implement the REDD + related projects have often been considered as paradoxical and some commentators raised concerns

${ }^{7}$ Marginalized communities are socially excluded groups of people including Dalit, women and Janajati (ethnic communities). 
that this might undermine their core responsibility of defending rights and safeguarding against any possible negative consequences of the REDD+ regime. While sometimes, NEFIN has antiREDD claims but at other instances, it also brings forward the agenda promoting REDD + implementation. We highlight the paradoxical role of these civic actors in REDD + implementation that might undermine the voice and concerns of the constituencies (see Section five).

The REDD+ readiness process in Nepal, driven from the framework of international agencies (i.e. FCPF) and dominated by expert led process (Ojha et al. 2013; Bushley 2014) has been criticized for limited representation of local community and indigenous people. The process is suggested to have provided disproportionately higher level of emphasis on the technical issues like determining reference level, MRV (monitoring, reporting, and verification) and limited attention were paid on some of the pertinent governance and policy issues (Ojha et al. 2013; Bastakoti and Davidsen 2014). Reflecting on this, one could ask whose voice the CSOs are representing, what are the underlying interests behind their involvement in REDD + interventions and what it implies in terms of representation of local voice in the REDD + policy and practices?

\section{ASSESSMENT OF THE REDD+ PILOTING}

We examine the process of design and implementation of the pilot project in CFs. The NORAD funded REDD+ pilot project (hereafter referred as project or pilot project interchangeably) was implemented in Nepal during 20092013 with its objective to 'demonstrate' $\mathrm{REDD}+$ implementation in CF. The project implementation was led by the International Center for Integrated Mountain Development (ICIMOD) ${ }^{9}$ with two national organisations: the Asia Network for Sustainable Agriculture and Bio-resources (ANSAB) - a Kathmandu based Non-Governmental Organisation (NGO) working in the field of biodiversity, and FECOFUN. The project was implemented in three selected catchments, one in each of three Nepalese districts; Charnawati in Dolakha district, Ludikhola in Gorkha district and Kayarkhola in Chitwan district (see figure 1). The project in total covered 105 CFUGs (58 in Charnawati, 31 in Ludikhola and 16 in Kayarkhola). Dolakha and Gorkha consist of mountain landscapes with similar forest types whereas the site in Chitwan consists of foothill of mountain (Chure) and Terai (see figure 1).

\section{Interventions and Logic}

The pilot project had two major focuses: demonstrating carbon sequestration and equitable distribution of payments. To demonstrate carbon sequestration, the project included interventions for enhancing carbon sequestration and establish a monitoring mechanism. Another important intervention was related to equitable payment of the REDD + fund to the CFUGs and ensure safeguard livelihoods of people. In this section, we discuss these interventions focusing on their logic and how they look like on the ground.

8 Interview, September 2014

9 ICIMOD is a regional intergovernmental in the Hindukush Himalayan region focusing on learning and knowledge sharing. 
Driven from the idea of making carbon monitoring cost-effective, the pilot focused on local participation in carbon measurements in the forests. The pilot developed guidelines including tools and procedures for carbon measurement and accounting (ANSAB 2010). Then, it selected members from the CFUGs, provided them with training who were later involved in taking specific measurements. However, the calculations and accounting of carbon was done by forest technicians employed by one of the project proponents. Using this approach, the baseline measurements of the above ground biomass, below ground biomass, litter and debris were taken in FebruaryApril 2010 by establishing sample plots within project sites. The amount of carbon stock was determined and a database was maintained at the project level (Pandey et al. 2014). Measurements were then repeated in each CFUG every year until the end of pilot project in 2013 to determine the increment in carbon stock following which, the payment was determined.

The project also included some interventions in the CFUGs intended to enhance carbon sequestration as planting tree species, protection of forest from fire and grazing and the introduction of improved cooking stoves and alternative energy schemes (i.e. bio-gas). The paper reports that about 200,000 seedlings were planted in 168 hectares across three sites, 448 biogas plants were installed, and 1490 improved stoves were distributed (Shrestha et al. 2014:7). In addition, the project also required the CFUGs to invest at least
40 per cent of the carbon payments on activities that improve forest management. Under the forest conservation theme, the activities listed in the (Forest Carbon Trust Fund - FCTF) Operational Guidelines ${ }^{10}$ included activities such as prevention of fires, controlling open grazing and planting trees.

Another important aspect of project intervention was the equity consideration in REDD + payment for which a formula was devised to determine the level of payment to each CFUG (ICIMOD et al. 2011; Skutsch et al. 2012). When determining the level of REDD+ payments (received from NORAD) to the CFUGs, 60 per cent weight was assigned to the socio-economic characteristics of the CFUG and 40 per cent according to the carbon increment.

REDD payment $=f$ [forest carbon pool (24\%)+ change in forest carbon $(16 \%)+$ number of housebolds of indigenous people (10\%)+ number of Dalit households (15\%)+ population of women (15\%)+ population of poor people (20\%)]

REDD + payments to the CFUGs were made in three subsequent years (2011 to 2013) following the above-mentioned formula. Whether payment levels based on this technical formula address or compensate (through what are essentially social welfare payments) for these complex social issues and underlying inequalities is a question. Project interventions were also designed to ensure that the REDD+ fund was used to support livelihood of some targeted groups (i.e. Dalit, women,

${ }^{10}$ FCTF was created as a mechanism to make payments to user groups for conserving carbon, with support from NORAD. 
indigenous and poor) within the CFUGs in the form of support to vegetable farming, buffalo calves and seed-goat distribution, and capacity development of the users.

Poverty reduction and livelihood improvement activities were also included in the FCTF Operational Guidelines as activities qualifying for expenditure of REDD + payments, and programs on awareness and capacity building on REDD + and climate change were targeted to Dalits and indigenous people. Hence, the project required the CFUGs to invest at least 50 per cent of the fund received in the form of carbon payments targeting these groups. The payments were made in different installments and the CFUGs were required to show that the amount was used as per the FCTF guidelines. According to Shrestha et al. (2014), this was achieved and about 50 per cent of the total REDD+ income was spent on activities related to livelihood improvement. The rest 10 per cent of the payment was used on CFUG's administration and activities related to trainings. Safeguard was one of the key issues in REDD + debate during the project period. Moreover, these considerations were also linked to the widespread equity concerns raised by the critics of REDD+. Yet, the extent to which the formulaic interventions address the equity issue and contribute to improve livelihood is a matter of further discussion which we elaborate in the following section.

\section{Consequences of the Interventions}

While reporting the achievements of the pilot project, the proponents claimed that the project demonstrated feasibility of implementation of REDD+ in CF without compromising the existing rights of people and the benefit they derive from the existing management practices. They further claimed that REDD+ potentially strengthens $\mathrm{CF}$ through increased financial flow. However, our ethnographic field study shows that the pilot interventions, driven from its narrow objectives, have posed risks that weaken decentralization by limiting the CFUGs' ability to make independent decisions. As we show, the pilot downplayed the possible negative consequences of REDD + implementation on the rights of community and wide range of benefits that people are deriving from the current CF management. First, the carbon-centric interventions as outlined above (section 4.1) carry potential risks of undermining the diverse ES that the existing CF management provides to the community. The findings showed that such interventions reshape forest-management priorities towards carbon outcomes which undermines the existing priorities of meeting local needs. Second, the formulaic approach taken by the pilot to address the equity concerns has minimalist impact on both equity and livelihoods. Inclusion of the social-criteria into a formula seems to have oversimplified the complex social issues which are less likely to resolve the equity issue that has prevailed in the CFs. Instead, the rules introduced during the piloting for meeting carbon and equity related objectives undermined the long standing decentralised practices in community forestry.

Improvement in provisioning of the basic forest products was regarded as the main achievement of the lauded community forestry programme in Nepal. Findings of the research, of which this paper is a part of, also showed that people derive a range of forest products and services i.e. timber building material, fuel-wood as 
household energy, and fodder and litter for maintaining livestock which forms an integral part of subsistence farming system in Dolakha and Chitwan (Marquardt et al. 2016). In this backdrop, concerns have been raised on whether REDD+ implementation can cast some negative consequences on local rights (Bushley and Khatri 2011; Bastakoti and Davidsen 2014; Paudel et al. 2015; Khatri et al. 2018).

However, the project appeared to have downplayed these consequences. The project interventions became part of the community forestry objective and reinforced the ongoing interests of CFUG leadership (elites) to prioritise revenue generation and forest conservation. The CFUGs have tightened the rules related to use of the forests. A Dalit from Boch village shared that they are not allowed to collect forest products from the REDD+ pilot site but earlier, they were allowed to collect leaf litter and firewood ${ }^{11}$. The relatively wealthier farmers obtained fodder and other tree products from trees planted on their private farm land and were therefore not necessarily affected by a more restricted access to CF. Farmers in a group meeting in Bhitteripakha CFUG commented that with the exception of the extremely poor household with no land and those involved in wage labor, poorer farmers need to access forest for fodder and other products because their own farm land are not large enough to grow trees and fodder. One farmer from Bhitteripakha CFUG $^{12}$ noted while complaining about the restriction in grazing after the implementation of REDD + in CFUG by saying:
I need to bring my cattle in community forest because I do not bave adequate fodder to feed them. I keep a buffalo and a few cows shared with a neighbor. $I$ bear from neighbors that leaders from the CFUGs are planning to ban grazing even in the small patch that was left. If it happens, I cannot manage to keep cattle. I neither can afford to buy improved breed cow or buffalo nor feed them which require good quality fodder.

This finding is consistent with other studies which report that CFUG rules related to access to grazing and collection of other forest products have become tighter after the pilot project implementation (Saito-Jensen et al. 2014; Poudel et al. 2014). Some studies reported that REDD + could affect the smallholders adversely by limiting their access to forest products, as one of the several dimensions affecting the Nepalese poor (Neupane and Shrestha 2012; Maraseni et al. 2014). However, these findings are not consistent with what the proponents of pilot claimed about the project's contribution to improvement of local livelihoods. The project interventions focused on using the REDD + money to improve livelihoods of poor and marginalised groups.

Rules and processes to allocate the benefits equitably is the most critical and challenging goal to achieve equitable benefit sharing (Sherpa and Brower 2015). The use of the social categories particularly ethnicity as payment criteria created tensions in some groups. Satio-Jensen et al. (2014) observed similar issues in Gorkha and argued that the so-called positive discrimination raised

${ }^{11}$ Interview with dalit farmer, February 2013

${ }^{12}$ Interview, November 2014. 
social tensions in the group. A study of five CFUGs in Gorkha reported that the positive discrimination in REDD+ payment promoted the project to include certain categories in the payment criteria. Groups having relatively smaller number of Dalit and Janajati population had complained that they felt dis-incentivised because of such 'discriminatory' rules. There were also instances of using fake figures of the number of households of socially marginalised households in Kankali CFUG to lure receiving greater fund. Also, the REDD+ coordinator of Kayerhola watershed in Chitwan shared about the repetitive benefits received by some households owing to the double sharing of headings (women, IPs, Dalits, poor) while some did not fulfill the criteria. He explained:

If I am indigenous and poor and have female in my family, then I would be counted under 3 headings and get more amount. But if a Chbetri/Brabmin is poor, then that household would be counted under poor and women only. Hence, the headings are duplicated. ${ }^{13}$

At the same time, identification of the actual needs of communities for benefit sharing is important prior to developing guidelines for benefit-sharing (Gebara 2013). There are instances of the REDD+ benefits not reaching the targeted groups the poor households. In Kankali CFUG ${ }^{14}$, the group invested REDD+ income to dig a fish pond with the idea that the poor Dalit families would be able to farm and sell fish for additional income. However, the Dalit households could not afford the initial investment to start the fish farming. The CFUG then leased the pond to a group of local people and decided that 80 per cent of the profit from the fish farming would go to the poor Dalit families. However, according to the CFUG leader, the fish pond had not yet rendered any economic return and therefore, the beneficiaries had not received any money so far. One of the Dalit men, part of the targeted group of the fish pond initiative said, "We have not received even a single Rupee from this fish pond. The group promised to provide us fifty thousand Nepalese Rupees (NRs.) last year, but we have not received it yet" ${ }^{15}$.

As Sherpa and Brower (2015) noted, elite members of communities intend to control benefits. Evidence of the increased elite capture, corruption, and the alliance of local elites with external actors have been reported by other studies (Bastakoti and Davidsen 2017). Also, support on animal husbandry through REDD+ payment in Chitwan appeared to be ineffective in Chepang communities as they do not have grazing lands. REDD + coordinator ${ }^{16}$ at the watershed level (Kayerkhola watershed) shared:

The poor who need to earn their day-today living by labor work are restricted to their homes to care for their goats or buffalo supported by REDD+ project. It's a problem for those poor people. During the last monitoring, we found that for around 40 per cent households, such animals were burden as they do not have chances to go out to earn.

\footnotetext{
${ }^{13}$ Interview, July 2016

${ }^{14}$ Interview, November 2015

${ }^{15}$ Interview conducted in February 2015 with a Dalit man who was selected as one of the beneficiaries of REDD + money.

${ }^{16}$ Interview with the REDD + Coordinator, July 2016
} 
$\mathrm{He}$ added that the REDD+ program could be beneficial on whole but not so effective for the individual households. $\mathrm{He}$ admitted that only a few households have benefited from the livelihood support activities (buffalo calf, goats or pigs).

Data from the five REDD+ CFUGs in Dolakha on their investment of the REDD + money shows that the support provided to the targeted households was made as an interest free loan with a payback period of six months to two years. A loan of about US\$15-60 to each household was provided to the poorest households to buy animals, invest in vegetable farming or start a small business. During an interview, one poor farmer from Bolde Setidevi ${ }^{17}$ CFUG of Dolakha district said:

I got 5000 Rupees from the CFUG for buying a goat. The goat died after few months but the CFUG asked me to pay the money back in one year. I had to sell another goat that I already had. The CFUG sent a letter asking me to pay the money back. I do not understand why they have not extended the time for payback.

As the above findings showed, providing a loan for a market-based activity imposes risks on the recipient(s) of such loan(s). Not only are such individuals poorly placed to carry additional risk, but such loans do not necessarily lead to increased income.

\section{INCORPORATION OF LOCAL VOICES INTO THE REDD+ DISCOURSE}

As discussed above, mobilization of community was the key approach of the piloting. The CFUGs and their members were key vehicles to undertake project activities and achieve its objectives. As we show in this section, the CFUG leaders have been mobilized or used instrumentally to achieve the REDD+ objectives i.e. implementation of interventions. Moreover, FECOFUN was involved in the implementation of the piloting, particularly at the local level, which was not simply a coincidence but a strategic choice by the project for effectively mobilizing the CFUGs. Such strategic mobilization eventually turned the community and activists into advocates of REDD +. We discuss how communities were mobilized in the project and how that shaped their attitude to and expectation from REDD+.

REDD + was portrayed by the proponents of the pilot as a win-win approach i.e. conserving forest along with supporting livelihoods. REDD + was portrayed among the CFUGs and FECOFUN officials as a source of additional revenue which helps to accomplish their objectives. A FECOFUN official in Dolakha called the representatives of all the CFUGs that were included in the catchment Charange Khola (stream) which was identified as one of the project sites by the proponents of the project in Kathmandu. The Dolakha FECOFUN was asked to organise a oneday workshop in Charikot (headquarter of the district) led by the project officials from Kathmandu. As reported by a FECOFUN official, "The [project] staff from Kathmandu explained about REDD + and its benefits to the invited CFUGs from the [proposed] project site and local level staff and FECOFUN representatives. The

\footnotetext{
${ }^{17}$ Interview with a poor farmer, February 2013
} 
CFUGs were asked to hold workshops in their respective groups and make a decision if they wanted to take part in the pilot project"18. CFUG leaders in a group meeting in Bhitteripakha reported that the "FECOFUN facilitators came to our group assembly and told us about REDD + and its benefits. They explained that REDD+ supports sustainable management of the forest and provides money to the group. They said that this money could be mobilized for forest management as well as to support the poor within the group. We decided to join the pilot project as we did not want to lose the opportunity ${ }^{19}$ ". All 58 CFUGs included in the catchment unanimously decided to take part in the project from their groups' meeting called 'general assembly'.

However, not everyone had the same level of understanding about REDD + and what implications it would have on their daily lives. Many of the ordinary users of the CFUGs had limited knowledge about what was happening under the pilot and what it would mean for their daily practices in managing and using forests. Only a limited number of CFUG leaders (mostly elites) were active in the project related activities. Most of the ordinary farmers interviewed in Dolakha and Chitwan had a rather limited awareness of the project except those in the CFUG leadership and those who received financial benefit or loan from it. Similar findings were reported by other studies. For example, Paudel (2014) reports that most of the households interviewed in nine CFUGs in the Charnawati watershed in Dolakha were unaware of REDD+ implementation and associated benefits. Further, Patel et al. (2013) reported that the feelings of mistrust among CFUG members grew as the community leaders had not provided clear information to the general members.

One poor farmer said "I don't participate in the CFUG meetings or in REDD+ activities because I have to work on my field or go for labor work to feed my family. I do not have the possibility to give up my work to participate in CFUG meetings" ${ }^{20}$. Maraseni et al. (2014) reports that the increased participation in the number of meetings and discussions would involve considerable time and labor. So, participation would remain temporary if the costs are not compensated for. Along this line, he also referred to 'consultation fatigue' the users face in the absence of compensation. Other families interviewed also reported that they were only aware that the CFUG was receiving money under REDD + but were vague about the details. A middle-income farmer from Bhitteripakha CFUG for instance, reported that "Only the chairperson and a few members from the CFUG executive committee were active in the REDD+ related activities. We went a couple of times to the CFUG assembly and heard that the group can get some money for conserving the forest" ${ }^{\prime 2}$.

Poor knowledge and awareness on REDD + among general members of CFUGs are also linked with the complex language and technical jargons involved in the REDD+ processes. The participants

\footnotetext{
${ }^{18}$ Interview with FECOFUN officials, February 2013.

${ }^{19}$ February 2013

${ }^{20}$ Interview with farmer of Thansa Deurali CFUGs, November 2013.

${ }^{21}$ Interview, April 2014
} 
during the District Level Stakeholder Consultation $^{22}$ on R-Package held in Chitwan expressed confusion about REDD + piloting and actual REDD+ implementation. A participant from one of the CFs within Kayerkhola watershed said, "You said that Nepal has not signed agreement on REDD + with the developed countries. If that's the case, how did Kankali CFUG receive the money?" Further, the projects used technical jargons which are incomprehensible to local communities. For example, the CFUG chairperson of Chelibeti CFUG in Chitwan, handed over the brochure to us (researchers) during our field visit as they could not understand the document (which was in English language) that was distributed to them in one of the district level consultations. Hence, there are reasons to question the quality of participation of different social groups in REDD + activities and hence project's contribution to enhance CFUG governance.

However, the quote at the beginning of this paper shows how REDD + was perceived by the local FECOFUN activists. The district FECOFUN representatives were amongst the strongest advocates for the REDD + pilot project in part because they were its local level implementation partner. They were reluctant to engage in a critical discussion about REDD+. The FECOFUN office holders rejected the possibility of any negative effects of REDD + on CFUGs or the livelihoods of the poor. A femaleFECOFUNleaderstated that "REDD + is an additional benefit to the CFUGs for their contribution to forest management. I hope all the other CFUGs from the district will also get the chance to take part in the REDD + mechanism and get benefits" ${ }^{23}$. She outright rejected any critical comments about REDD+. They seem to have overlooked any negative consequences of REDD + on the rights of the community on management and use of forest.

Such a positive view from FECOFUN, despite its membership base, could perhaps be expected given its role as a project partner. The local FECOFUN appeared to advocate more about the benefit of the pilot project rather than act as the defender of local interests. Such paradoxical role of the CSOs and the instrumental use of the local forest user groups driven by the interests of the external actors to make REDD + work in community forestry arguably might subsume the local interest that underlies CF management and the benefit it is providing to people.

\section{WHAT DOES REDD+ IMPLEMENTATION MEAN FOR CF GOVERNANCE?}

In this paper, we aimed to contribute to the ongoing debate on REDD + and forest decentralisation by examining Nepal's REDD+ development and implementation. The findings showed limited representation of local voices in the REDD + policy development and implementation of the pilot. The pilot examined in this paper constituted of technical logic and formulaic interventions and has limited effects on supporting local livelihoods. Instead, the interventions have

\footnotetext{
${ }^{22}$ The program 'District level Stakeholder Consultation' was organized by Arbonaut on R-Package where the representatives from different Community Forests of Kayerkhola watershed, NEFIN, FECOFUN, media persons participated; held on March 2015.

${ }^{23}$ Interview, April 2014.
} 
reshaped the community forestry objective and priorities posing risk to limiting local access to forest benefits. The REDD+ development and implementation process enrolled the key CSOs and local CFUGs into mainstream discourses as win-win approach, silencing the space for local voices.

Sandbrook et al. (2010) argued that the financial incentive associated with REDD + regime will raise the value of the forests which, "tend to increase the political incentive for central government bureaucracies to retain or recentralise control over forests" (pp. 332). Phelps et al. (2010) argue that the level of technical sophistication required for monitoring and demonstrating emission reduction to implement REDD+ will demand more centralised governance and hence, reverse the trend of decentralisation. It is not only the inherent nature of REDD+ architecture that contradicts with the principle of community forestry, but our analysis also showed that the way in which REDD + policy has been developed and interventions are undertaken provide limited space for participation and representation of local voices which can weaken spirit of forest decentralisation (Bushley and Khatri 2011; Ojha et al. 2013; Khatri et al. 2018). Some recent studies indicate that the technical and financial logic of REDD + can reshape the objectives and practices of CF management driving further away from the need to meet local livelihood needs (Khatri et al. 2018).

Buizer et al. (2014) pointed out that the international climate initiative such as REDD+ "do not land intact in the ground” (pp.3). Rather, they interact with local institutions and practices (i.e. community forestry in case of this study) which determines the outcomes of the regime at the local level. As findings showed, REDD + lands on the context of CF with established institutional mechanisms involved in managing forests for local benefits.

While implementing the pilot, local participation was used in instrumental way and the local forest user groups and CSOs were drawn into the REDD+ discourses of conserving carbon (Leach and Scoones 2015; Arora-Jonsson et al. 2016) which has limited the space for local voices to be reflected in the national policy processes (Ojha et al. 2013). Our findings are consistent with other studies that policy development was influenced by experts and international organisations with limited representation of the voice of the local people (Bushley and Khatri 2011; Ojha et al. 2013; Satyal et al. 2018).

The project interventions carried out to meet the project's objectives of demonstrating carbon sequestration whilst ensuring equity in benefit distribution have influenced CFUGs' management practices. Promotion of the carbon-centric management in the CFUGs have posed risk of encouraging carbon monoculture in $\mathrm{CF}$ which eventually undermines the multiple ecosystem benefits that local people derive from the landscape that plays a vital role in maintaining subsistence farming prevalent in the Nepalese mountains (Marquardt et al. 2016). This indicates increasing risk of local benefits to be threatened by technocratic logic of the REDD+ design and implementation (Groom and Palmer 2012). Our analysis also showed that formulaic interventions have limited effects in supporting local 
livelihoods. The interventions that intend to address the existing dynamics of inequality in $\mathrm{CF}$ require challenging the power structure (Peskett et al. 2011; McDermott et al. 2013; Di Gregorio et al. 2013). However, the piloting interventions helped in reinforcing the existing power structure. The findings are also consistent with the argument that adopting a multidimensional approach is important when identifying beneficiaries and benefits (Gebara 2013) and in case of not effectively considering structural inequality, the REDD+ benefit distribution would sideline the marginalised people (Chomba et al. 2016).

The project mobilized the CFUG and its network (FECOFUN) in implementation of the project and this has also posed threats to decentralisation, which contradicts with the claim made by the advocates of REDD+ (i.e. Skutch et al. 2012). The proponents of the pilot claimed that it mobilized the groups in forest management and developed capacity of local institutions including FECOFUN (ibid), which they asserted, strengthens decentralised governance. However, our analysis showed that the CFUGs were mobilized in more instrumental way to meet the REDD+ goal i.e. enhancing carbon and ensuring cost-effective carbon measurement. Moreover, involvement of FECOFUN, whose main role has been to defend the local rights, in implementation of the project also seemed paradoxical. As the quote from community activist in introduction explained, this process made FECOFUN, the advocates of REDD + . The role of a prominent activist organisation seemed contradictory and detrimental to the safeguarding of the local rights (Ojha et al. 2013).
The proponents of REDD + in Nepal such as the World Bank considered involvement of CSOs in the national policy process as an achievement in terms of inclusive and participatory policy process. The participation of CSO representing indigenous peoples and local communities in the national REDD + policy processes is considered to be critical in the design and implementation of REDD+ policies and projects (Brockhaus et al. 2014; Pham et al. 2014; Bastakoti and Davidsen 2014). Yet, studies indicate the risk of participatory exclusion and technocratic dominance in the policy process (Agarwal 2001; Ojha et al. 2013). Satyal et al. (2018) maintained that spaces for participation and decisionmaking in REDD + have been defined and dominated by government actors and influential civil society groups, whereas the influence of other actors, particularly marginalised groups such as Dalits and women's organisations, have remained limited. Moreover, the representation of the voice of specific social groups especially the Dalits and women by other civil society groups have not been effectively put forward. Similar argument is put forward in other studies that power and influence by the state or other political actors in line with long-term political norms limit the ability and conducive environment for civil society to raise issues of specific social groups in national REDD+ policy processes (Mason 2010; Scholte 2011).

At the same time, it has been argued that ensuring participation of community representatives at different levels of REDD + governance has been considered to be instrumental to ensure 'social safeguard' (see Chhatre et al. 2012). Full and effective participation is also considered to be important in decision-making processes, 
project implementation and monitoring at the local level in determining equitable REDD + benefit distribution (Lindhjem $e t$ al. 2010; Gebara 2013; Pham et al. 2013) and for minimising negative impacts of REDD + on livelihoods (Bayrak and Marafa 2016). Moreover, studies suggest that both socio-economic and ecological factor play role for household participation in forest management (Shrestha and Shrestha 2017). However, findings presented above showed that the voices of the marginalised social groups were not effectively represented by influencing civil society groups.

We argue that the paradoxical role of the citizen network like FECOFUN as implementing agency and becoming advocates of the international regime weakens the local critical voice and agency to safeguard the local rights. This links to the argument of some commentators like Beymer-Faris and Bassett (2012) ${ }^{24}$ that empowering local communities and their agency can be instrumental to resist any possible negative consequences of the REDD + regime. The issue of safeguard of local rights has high significance when REDD+ lands on the ground where there is the pre-existing well-established community forestry which is credited for improving the supply of forest products and services which is vital for subsistence small-holder farmers.

\section{CONCLUSION}

Findings presented in this paper showed that the REDD+ policy development and piloting initiative is likely to weaken Nepal's established community forestry rather than strengthening it. REDD+ development used participation in more instrumental way and there was limited representation of the voice of the local communities and indigenous peoples. The role of key CSOs appeared paradoxical and their ability to represent local voices was weakened due to their involvement in project implementation which made them advocates for REDD+. The piloting, which was focused on demonstrating REDD + implementation in CF, included technical and formulaic interventions and approaches focused on meeting project objectives redefined the forest management priorities leading towards more restrictive practices for local uses of forest. Further, the effects of the piloting on local livelihoods were limited; instead, restrictive rules limited the locals' access. The local voices were incorporated into the mainstream discourse of REDD+ i.e. win-win solution of addressing deforestation and poverty. The way CSOs were involved in the policy process and project implementation weakened their ability to represent local voices. Hence, the concerns of the locals were poorly represented in policy development and project implementation. These findings suggest the need for greater attention towards representation of local voices in designing policies and projects to safeguard the local rights and benefits in CF under the age of REDD+.

\section{ACKNOWLEDGEMENT}

This paper draws on two separate studies and the authors acknowledge the funding provided by the Swedish Research Council

\footnotetext{
${ }^{24}$ Beymer-Farris and Bassett (2012) argued that local resistance could be the potential measure for depend the 'REDD menace' in the Rufiji Delta of Tanzania.
} 
(RV-2011-39 580-84834-46) and the Netherlands Organisation for Scientific Research (grant no. W 07.68.415). We thank Hemant Ojha, Adam Pain, Kristian Marquardt, Andrea Nightingale and Hari Dhungana for their valuable comments and insights.

\section{REFERENCES}

Adhikari, B., Williams, F. and Lovett, J.C. 2007. Local Benefits from Community Forests in the Middle Hills of Nepal. Forest Policy and Economics, 9: 464-478.

Agarwal, A., Perrin, N., Chhatre, A., Benson, C.S. and Kononen, M. 2012. Climate Policy Processes, Local Institutions, and Adaptation Actions: Mechanisms of Translation and Influence. Wiley Interdisciplinary Revieres: Climate Change, 3: 565-579.

Agarwal, B. 2001. Participatory Exclusions, Community Forestry, and Gender: An Analysis for South Asia and a Conceptual Framework. World development, 29: 1623-1648.

Agrawal, A., Chhatre, A. and Hardin, R. 2008. Changing Governance of the World's Forests. Science, 320: 1460-1462.

ANSAB. 2010. Forest Carbon Stock in Community Forest of three Watersheds (Ludikhola, Kayarkhola and Charnawati). Asia Network for Sustainable Agriculture and Bioresources, Kathmandu, Nepal.

Arora-Jonsson, S., Westholm, L., Temu, B.J. and Petitt, A. 2016. Carbon and Cash in Climate Assemblages: The Making of a New Global Citizenship. Antipode, 48: 74-96.

Bastakoti, R. and Davidsen, C. 2017. Optimism, Hopes and Fears: Local Perceptions of REDD+ in Nepalese Community Forests. International Forestry Revierw, 19: 1-16.

Bastakoti, R.R. and Davidsen, C. 2014. REDD+ and Forest Tenure Security: Concerns in Nepal's Community Forestry. International Journal of Sustainable Development \& World Ecology, 21: 168-180.

Bayrak, M.M. and Marafa, L.M. 2016. Ten Years of REDD+: A Critical Review of the Impact of REDD+ on Forest-Dependent
Communities. Sustainability, 8(7), 620. https:// doi.org/10.3390/su8070620

Beymer-Farris, B.A. and Bassett, T.J. 2012. The REDD Menace: Resurgent Protectionism in Tanzania's Mangrove Forests. Global Environmental Change, 22: 332-341.

Brockhaus, M., Di Gregorio, M. and Mardiah, S. 2014. Governing the Design of National REDD+: An Analysis of the Power of Agency. Forest Policy and Economics, 49: 23-33.

Buizer, M., Humphreys, D. and De Jong, W. 2014. Climate Change and Deforestation: The Evolution of an Intersecting Policy Domain. Environmental Science E Policy, 35: 1-11.

Bushley, B.R. 2014. REDD+ Policy Making in Nepal: Toward State-Centric, Polycentric, or Market-Oriented Governance? Ecology and Society, 19.

Bushley, B.R. and Khatri, D. 2011. REDD+: Reversing, Reinforcing or Reconfiguring Decentralized Forest Governance in Nepal. Discussion Paper, ForestAction Nepal, Kathmandu, Nepal

Chhatre, A., Lakhanpal, S., Larson, A.M., Nelson, F., Ojha, H. and Rao, J. 2012. Social Safeguards and Co-Benefits in REDD+: A Review of the Adjacent Possible. Current Opinion in Environmental Sustainability, 4: 654660.

Chomba, S., Kariuki, J., Lund, J.F. and Sinclair, F. 2016. Roots of Inequity: How the Implementation of REDD+ Reinforces Past Injustices. Land Use Policy, 50: 202-213.

Di Gregorio, M., Brockhaus, M., Cronin, T., Muharrom, E., Santoso, L., Mardiah, S. and Büdenbender, M. 2013. Equity and REDD+ in the Media: A Comparative Analysis of Policy Discourses. Ecology and Society, 18.

DoF. 2018. Community Forestry Database. Department of Forests, Mininstry of Forest and Environment, Government of Nepal, Kathmandu, Nepal.

Gautam, A.P., Webb, E.L., Shivakoti, G.P. and Zoebisch, M.A. 2003. Land Use Dynamics and Landscape Change Pattern in a Mountain Watershed in Nepal. Agriculture, Ecosystems $\mathcal{E}$ Environment, 99: 83-96. 
Gebara, M.F. 2013. Importance of Local Participation in Achieving Equity in BenefitSharing Mechanisms for REDD+: A Case Study from the Juma Sustainable Development Reserve. International Journal of the Commons, 7.

Groom, B. and Palmer, C. 2012. REDD+ and Rural Livelihoods. Biological Conservation, 154: 42-52.

ICIMOD, FECOFUN, and ANSAB. 2011. Operating Guideline of Pilot Forest Carbon Trust Fund (FCTF), Developed Under Project on Design and Setting up of a Governance and Payment System for Nepal's Community Forest Management Under REDD. Kathmandu, Nepal.

Khatri, D.B., Marquardt, K., Pain, A. and Ojha, H. 2018. Shifting Regimes of Management and Uses of Forests: What Might REDD+ Implementation Mean for Community Forestry? Evidence from Nepal. Forest Policy and Economics, 92: 1-10.

Leach, M. and Scoones, I. 2015. Carbon Conflicts and Forest Landscapes in Africa. Routledge.

Lindhjem, H., Bråten, I.A.K., Gleinsvik, A. and Aronsen, I. 2010. Experiences with Benefit Sharing: Issues and Options for REDD-Plus. Econ Pöyry and Vista report R-2010-018.

Maraseni, T., Neupane, P., Lopez-Casero, F. and Cadman, T. 2014. An Assessment of the Impacts of the REDD + Pilot Project on Community Forests User Groups (CFUGs) and their Community Forests in Nepal. Journal of environmental management, 136: 37-46.

Marquardt, K., Khatri, D. and Pain, A. 2016. REDD+, Forest Transition, Agrarian Change and Ecosystem Services in the Hills of Nepal. Human Ecology, 44: 229-244.

Mason, M. 2010. Information Disclosure and Environmental Rights: The Aarhus Convention. Global Environmental Politics, 10: 10-31.

Mcdermott, M., Mahanty, S. and Schreckenberg, K. 2013. Examining Equity: A Multidimensional Framework for Assessing Equity in Payments for Ecosystem Services. Environmental Science E Policy, 33: 416-427.

Neupane, S. and Shrestha, K. K. 2012. Sustainable Forest Governance in a Changing Climate:
Impacts of REDD Program on the Livelihood of Poor Communities in Nepalese Community Forestry. International Journal of Sustainable Development, 4(1): 71-82.

Newton, P., Schaap, B., Fournier, M., Cornwall, M., Rosenbach, D. W., Deboer, J., Whittemore, J., Stock, R., Yoders, M., Brodnig, G. and Agrawal, A. 2015. Community Forest Management and REDD +. Forest Policy and Economics, 56: 27-37.

Niraula, R.R., Gilani, H., Pokharel, B.K. and Qamer, F. M. 2013. Measuring Impacts of Community Forestry Program through Repeat Photography and Satellite Remote Sensing in the Dolakha District of Nepal. Journal of Environmental Management, 126: 20-29.

Ojha, H.R., Khatri, D., Shrestha, K.K., Bushley, B. and Sharma, N. 2013. Carbon, Community and Governance: Is Nepal Getting Ready for REDD +? Forests, Trees and Livelihoods, 22: 216229.

Pandey, S.S., Cockfield, G. and Maraseni, T.N. 2014. Dynamics of Carbon and Biodiversity under REDD + Regime: A Case from Nepal. Environmental Science \& Policy, 38: 272-281.

Patel, T., Dhiaulhaq, A., Gritten, D., Yasmi, Y., De Bruyn, T., Paudel, N. S., Luintel, H., Khatri, D. B., Silori, C. and Suzuki, R. 2013. Predicting Future Conflict under REDD+ Implementation. Forests, 4: 343-363.

Paudel, D. 1999. Distributional Impacts of Community Forestry Programmes on Different Social Groups of People in the Mid-Hills of Nepal. Master's thesis, University of Cambridge, UK.

Paudel, N.S., Vedeld, P.O. and Khatri, D.B. 2015. Prospects and Challenges of Tenure and Forest Governance Reform in the Context of REDD Plus Initiatives in Nepal. Forest Policy and Economics, 52: 1-8.

Peskett, L., Vickers, B. and Graham, K. 2011. Equity Issues in REDD. Working Paper Produced for the Project'Safeguarding Local Equity as Global Values of Ecosystem Services Rise.

Pham, T.T., Brockhaus, M., Wong, G., Dung, L., Tjajadi, J.S., Loft, L., Luttrell, C. and Assembe Mvondo, S. 2013. Approaches to Benefit Sharing: A Preliminary Comparative 
Analysis of 13 REDD + Countries. Center for International Forestry Research, Bogor, Indonesia.

Pham, T.T., Di Gregorio, M., Carmenta, R., Brockhaus, M. and Le, D. N. 2014. The REDD + Policy Arena in Vietnam: Participation of Policy Actors. Ecology and Society, 19.

Phelps, J., Webb, E.L. and Agrawal, A. 2010. Does REDD + Threaten to Recentralize Forest Governance. Science, 328.

Poudel, M., Thwaites, R., Race, D. and Dahal, G. R. 2014. REDD+ and Community Forestry: Implications for Local Communities and Forest Management- A Case Study from Nepal. International Forestry Review, 16: 39-54.

Saito-Jensen, M., Rutt, R. L. and Chhetri, B.B.K. 2014. Social and Environmental Tensions: Affirmative Measures Under REDD + Carbon Payment Initiatives in Nepal. Human Ecology, 42: 683-694.

Sandbrook, C., Nelson, F., Adams, W.M. and Agrawal, A. 2010. Carbon, Forests and the REDD Paradox. Oryx, 44: 330-334.

Satyal, P., Corbera, E., Dawson, N., Dhungana, H. and Maskey, G. 2018. Representation and Participation in Formulating Nepal's REDD+ Approach. Climate Policy, 1-15.

Scholte, J.A. 2011. Building Global Democracy? Civil Society and Accountable Global Governance. Cambridge: Cambridge University Press.
Sherpa, D. T. and Brower, A. L. 2015. Equity in Sharing the Potential Benefits of REDD + in Nepal. Journal of Forest and Livelihood, 13(1).

Shrestha, S. and Shrestha, U. B. 2017. Beyond Money: Does REDD+ Payment Enhance Household's Participation in Forest Governance and Management in Nepal's Community Forests? Forest Policy and Economics, 80: 63-70.

Shrestha, S., Karky, B. and Karki, S. 2014. Case Study Report: REDD + Pilot Project in Community Forests in Three Watersheds of Nepal. Forests, 5: 2425-2439.

Skutsch, M.M., Karky, B.S., Rana, E.B., Kotru, R., Karki, S., Joshi, L., Pradhan, N., Gilani, H. and Joshi, G. 2012. Options for Payment Mechanisms under National REDD+ Programmes. ICIMOD Working Paper 2012/6. International Center for Integrated Mountain Development, Kathmandu, Nepal.

Thoms, C.A. 2008. Community Control of Resources and the Challenge of Improving Local Livelihoods: A Critical Examination of Community Forestry in Nepal. Geoforum, 39: 1452-1465.

Vijge, M.J., Brockhaus, M., Di Gregorio, M. and Muharrom, E. 2016. Framing National REDD + Benefits, Monitoring, Governance and Finance: A Comparative Analysis of Seven Countries. Global Environmental Change, 39: 57-68. 